\title{
Model Regarding the Analysis of the Evolution of the Number of Pensioners and the Public Pension in Romania
}

\author{
Mădălina-Gabriela Anghel ${ }^{1}$, Dragoș-Alexandru Hașegan ${ }^{2}$ \\ ${ }_{1}^{1}$,Artifex" University of Bucharest, Romania, ${ }^{1}$ E-mail: madalinagabriela_anghel@yahoo.com \\ ${ }^{2}$ Bucharest University of Economic Studies, Romania, 2E-mail:dragos_has@yahoo.com
}

\begin{abstract}
This article consists of analyzing and identifying the concrete conditions of the evolution of the number of pensioners in Romania and of the average monthly pension obtained by these persons. The methodological aspects that define the economic categories and the calculated indicators are presented, in order to clarify and facilitate, for the sake of understanding, by all persons interested in studying this article. The analysis was performed on the total number of pensioners compared to the average pension and, last but not least, to the most complex indicator of results of the economy, the Gross Domestic Product. The two indicators I mentioned, the number of retirees and the average monthly pension, were analyzed on the basis of a simple linear regression function, considering that the average monthly pension also depends on the number of retirees, given that the pension fund is limited, and even if there are legislative enactments that increase these pensions from one period to another, this can sometimes result in the reduction or maintenance of a lower average pension growth rate.
\end{abstract}

Key words

Indicators, Statistical-Econometric Models, Pension System, Gross Domestic Product, Social Insurance, Economic-Financial Crisis, Pandemic

\begin{tabular}{|c|c|c|}
\hline Received: & 15 Mar 2020 & (c) The Authors 2020 \\
\hline Revised: & 22 Mar 2020 & Published by Human Resource Management Academic Research Society (www.hrmars.com) \\
\hline $\begin{array}{l}\text { Accepted: } \\
\text { led Online: }\end{array}$ & $\begin{array}{l}27 \text { Mar } 2020 \\
07 \text { Apr } 2020\end{array}$ & $\begin{array}{l}\text { This article is published under the Creative Commons Attribution (CC BY } 4.0 \text { ) license. Anyone may } \\
\text { reproduce, distribute, translate and create derivative works of this article (for both commercial and } \\
\text { non-commercial purposes), subject to full attribution to the original publication and authors. The full } \\
\text { terms of this license may be seen at: http://creativecommons.org/licences/by/4.0/legalcode }\end{array}$ \\
\hline
\end{tabular}

\section{Introduction}

In this article, the main purpose was to perform a complex analysis, based on the data series of thirty years we had, to highlight the evolution of the average monthly pension in Romania. The methodology used was presented and some methodological clarifications were made precisely in order to understand the statistical categories used and, in particular, the content of the indicators that we used in this analysis.

Thus, an analysis of the results of the last year of 2019 was made, highlighting an increase of the nominal and real pension. Also, comparing the evolution of the number of pensioners, it was analyzed what were the rhythm and the correlation between the two categories. There are times when, due to the period of economic and financial crisis 2008-2010, pensions decreased, but they were immediately reconsidered, neither such constitutional nor moral decision being made at the level of the economy in order to overcome the effects of a crisis, economic and financial.

We also conducted a brief analysis of these indicators in the last quarter of 2019 , compared to the same quarter of the previous year or compared to the previous quarter of the same year in 2019. The authors also discussed a broader, comparative analysis of those three indicators, with relevance in the evolution of the average pension in the public sector, namely the Gross Domestic Product, the number of 
pensioners, the change of this number and the evolution of the annual pension for the analyzed period of time. We used the annual pension because at certain time intervals, as a result of some changes in the legislation, there were also more substantial changes to this average annual pension.

At the end of the article, an analysis is made, based on statistical-econometric models, in this case using simple linear regression and multiple linear regression. The article did not focus on the presentation of the statistical-econometric aspects used, understanding that they are known by those who use them and we aimed to apply these models, in order to reveal, based on the calculated parameters, an estimate that would allow to identify the evolutionary trend of the average pension year. This analysis is tested to give results, one hundred percent, convincing in the context in which no force majeure elements appear at the level of economic evolution. Thus, at the moment, the data that need to be correlated with another forecast of the economic effects that the crisis caused by the pandemic of the coronavirus will have. We can anticipate right now, that at the level of the national economy, there will be a lot of activity restrictions, reducing economic results, as a consequence of reducing the level of economic growth, materialized in the value of the macroeconomic indicator Gross Domestic Product, which it will be calculated at the end of 2020.

From preliminary studies, it results in a reduction of at least $8-10 \%$ of the Gross Domestic Product that will be obtained by Romania in 2020, compared to 2019. Of course, this is only anticipation and not estimation on a scientific basis, which may be greatly modified, in a positive or negative sense, depending on the future spread of the pandemic crisis of this coronavirus.

\section{Literature review}

Andonov et al. (2018) analyzed the impact of investment decisions on the performance of public pension funds. Anghel \& Anghelache (2018) studied the number of pensioners in Romania, which is sufficiently large compared to the active work force, highlighting the increased difficulty for the working population, considering that there are other categories that are not engaged in the field of work. Anghelache (2018) carried out a complex analysis of the economic-social evolution of Romania in 100 years since the Great Union. Anghelache et al. (2011) addressed a number of issues regarding the pension calculation algorithm. Biggs (2014) researched elements regarding the level of contributions and investment risks in order to obtain an acceptable level of performance of public funds plans. Bohn (2011) tried to identify the effects of the possibility of full financing of public retirement plans. Bouchet et al. (2017) used a model to propose a pension reform capable of supporting a retirement system, in the face of profound demographic changes. Cai \& Stoyanov (2016) showed that demographic differences between countries are a source of advantage in international trade, many skills depending on age. Chen et al. (2016) looked at how risk generation is shared across pension funding. Hairault et al. (2010) dealt with issues regarding the employment of older workers and the extension of the retirement age. A similar theme is addressed by Vogel et al. (2017). lacob (2019) highlighted the importance of using econometric instrumentation in economic studies. Novy-Marx \& Rauh (2011) analyzed the various promises regarding the value of public pensions. Roeder (2014) referred to the relationship between the level of taxation and the optimal pension. St. Clair \& Martinez Guzman (2018) analyzed the factors that determined the states to engage in pension reform and especially the contribution volatility.

\section{Methodology of research. Results and discussions}

For an easier browsing and a better understanding of the content of the data presented and of the opinions expressed by the authors, we will summarize in the following the main methodological issues elaborated by the National Institute of Statistics, which refers to the main elements and indicators that characterize the pension system. Thus, the data collection process is carried out through statistical reports that are completed by the personnel from the specialized departments of the pension houses (National House of Public Pensions, Ministry of National Defense, Ministry of Internal Affairs, Romanian Information Service, Ministry of Culture and Identity and the Insurance House of Lawyers). The total average number of pensioners means the totality of the pensioners in Romania, irrespective of the pension system, respectively the public pension system and the systems not integrated into the public pension system. 
Thus, the total average number of pensioners is determined by summing the number of existing pensioners in payment each month, compared to the number of months in the reference period.

The average number of pensioners in the social insurance system includes state social insurance retirees, retirees from the former farmers insurance system, social insurance retirees from the Ministry of National Defense, the Ministry of Internal Affairs and the Romanian Intelligence Service, social insurance pensioners from the records of the Ministry of Culture and National Identity and the social insurance pensioners from the records of the Lawyers Insurance House.

For the determination of the average monthly pension, the pensions paid by the pension houses of all categories of social insurance, invalidity, survivors, pensioners, etc. are taken into account. The monthly average pension is calculated by comparing the amounts due to the existing pensioners in payment in the reference quarter/year to their monthly average number multiplied by 3 months, respectively 12 months.

The categories of pensions granted in Romania are: the old-age pension benefited by the persons fulfilling, cumulatively, at the date of retirement, the conditions regarding the standard retirement age and the minimum contribution period; the early retirement benefit of persons who have completed a contribution period at least 8 years older than the full contribution period no more than 5 years before reaching the standard retirement age; the partial early retirement benefit of persons who have completed the full contribution period, as well as those who have exceeded the full contribution period up to 8 years, at most 5 years before the standard retirement age is reached; the invalidity pension benefited by persons who have lost altogether or at least half their work capacity; the survivor's pension of the children and the surviving spouse, if the deceased supporter was a pensioner or fulfilled the conditions for obtaining a pension; the IOVR pensions that are granted to the disabled and the war victims, the survivors of the dead or missing in the war, as well as the survivors of the former invalid and injured pensioners of the war and the social assistance type pension that is paid from the State Social Insurance Budget.

For the calculation of the real pension, the net nominal average pension is established by deducting the tax from the amounts due as pensions and the contribution of social health insurance. The real pension expresses the value of the goods and services that can be bought and used, respectively, with the average net nominal pension in a certain period of time, compared to another period, considering the evolution of consumer prices and the tariffs of the services. The indicator is determined by taking into account the appropriate amounts for the pensions paid to the state social insurance pensioners and to the MApN, MAI, SRI pensioners.

The real pension index is calculated as a ratio between the nominal pension index and the consumer price index. The pension is the form of reward of an employee who contributed during his activity to the creation of a National Pension Fund. We need to make some clarifications, in the sense that all the contributors to the National Pension Fund should have no problem today in collecting their rights to the public pension, as it came from the point of view of the legislation in force overtime and especially from the point of view of individual contributivity.

Until recently, at the national level, there was only one pension fund, the one of the public pensions, to which any of those who have worked and will continue to have access and is also recognized as a form of its contribution to the National Fund for pensions.

The difficulty arises from 1990, when the form of association from agriculture and certain pension systems of special state institutions was abolished; it was created a single National Fund, in which state pensioners, pensioners for social insurance continue to operate. , old-age pensioners, retirees who came out before retirement, survivors' pension, sick or medical pension, all of these, however, should not create and should not have created a problem if, always, the pension fund would have it was created in a national fund, which was then made available to economic agents, institutions that could use these particular resources, to increase their value and, in terms of time given by the life expectancy limit, we find that in a percentage close to $95 \%$, those who worked until the retirement age, others and after this age, he receives the pension as a result of the activities for a shorter period, some even for a few years.

In the context in which this National Pension Fund would have been separately highlighted, managed and used separately, it would have been quite another situation, except that, always, the pension fund is paid to the state budget and then distributed to the respective pensions, sums that often contradict reality. 
In other news, pensions have always been regulated within the legal framework. Some provisions of the legislation on public pensions also take into account criteria other than that of the number of years and the contributory throughout the activity. The activities of group I or II are considered, where it is considered that the difficulties of the activity have required finding and other possibilities to reward this activity, either by leaving the pension earlier, taking into account the wear and tear of the activity carried out, either by finding other possibilities to stimulate a particular activity, we refer here to those with special pensions, or in other circumstances, to consider a certain basis to which the whole activity of the human being relates as years worked.

From this point of view there are some controversies, but they do not have to be the defining ones in analyzing and designing the public pension system. A part of those who were workers of the agricultural system, the former CAP, were also included in the pension system, who were granted a certain amount, which was later assimilated, not as social aid, but as a certain pension that it has entered the general system of legislation with increases and, so on, of the respective pensions.

From this perspective, two aspects are important, namely, firstly, that at European Union level there is a directive which provides for the continued use of the capacities of those who have reached retirement age if they are useful for the sectors of activity. , for research, for the activity of any kind, and on the other hand in understanding that some discrepancies exist between the pensions granted to some categories compared to the pensions granted to other categories. It is often considered that certain activities, such as piloting, in which the age until retirement is shorter, and wages are in accordance with the importance and responsibility, the physical and mental consumption of those working in this field, meaning in who have received and continue to receive sufficiently high salaries. This reward for their work carries with it, regardless of whether the payment is made by the employee or employer, and the contribution to social insurance. This point of view, if the law is pursued in its letter, based on criteria, which should not change from one period to another, the respective person who has worked in this field will look exactly at the value, as a pension, of the value with which he contributed to the National Pension System.

Here, in short, why we consider that an analysis of the evolution of the number of pensioners, in parallel with the evolution of the real and nominal average pension, is important in the context in which we must highlight the ability of these incomes obtained from pensions to ensure a decent standard of living of those in this situation. Of course, we cannot, especially in the current system where there is a pension budget, but in which these incomes are paid first to the consolidated budget and then distributed and considered as part of pensions from the consolidated state budget.

In this analysis we cannot omit the fact that in the population structure we can discuss four categories. On the one hand, we can discuss the economically active population, which includes all the people who provide the available labor force for the production of goods and services, during a reference period, including the employed population and the unemployed. We also say unemployed because they have a limited benefit, unemployment benefit, and they are always looking for a job. There are criteria according to which he must respond to job offers, and otherwise, if this does not happen, the unemployment benefit payment is suspended and he becomes unemployed.

The activity rate represents a share of the active population in the age group in the total population of that age group and we make this statement to show that there are certain age groups in which the active population is quite unconvincing. We can also calculate the activity rate of the working age population, representing here the share of the active population aged 15 to 65 years, in the total population aged 15 to 64 years.

An indicator even closer to the realities of a country's labor force system and reserves, represents the employed population, which includes all persons aged 15 years and above, who have had an economic activity producing goods or services for at least one hour, during the reference period in a week, in order to obtain income in the form of salaries, payment in kind or other benefits. The employed population is the basis of employment or from which the unemployed population is extracted. Of the employed population, those who work on a contract of employment for longer periods are represented by employees and other categories that carry out activity on their own account, in associative activities and so on.

In summary, in the fourth quarter of 2019 , the structure of the population of Romania was as follows: the active population 9,008 million people, the employed population 8,654 million people, 
including 354 thousand unemployed. The employees were 6.586 million people, and in other categories there were other PFA activities, self-employed activity etc., farmers and many others. From here we need to extract what is the situation represented by the real and possibly nominal average pension, the number of pensioners and then into consideration, taking into account the desire to obtain some data to ensure the real estimation and forecasts for the following periods, correlated with others of results of the national economy.

From this point of view, we took a series of data from 1990 to 2019, which we processed and adjusted, data that include the evolution of the Gross Domestic Product in millions of lei (Ron), the average number of pensioners expressed in millions and the average monthly pension obtained over the same period of three decades. The data are important, they are analyzed monthly, quarterly or according to the annual results, and in the wish to highlight the last evolutionary stage, we also referred to the average monthly pension and the number of pensioners over a three-year period 2017, 2018 and 2019.

The categories of pensions received, the total ones, of social insurances are highlighted, of which state social insurance, age limit, early retirement, partial invalidity early retirement or survivor's pension.

At the same time, we conducted a brief analysis regarding the actual value of the pension compared to the number of pensioners. The nominal pension is the one that receives, within a period of one month, a certain employee, and the real pension is precisely this nominal pension divided by the consumer price index, in other words, a deflated pension brought to the real level that it offers the market.

An analysis of the nominal evolution of pensions was performed and according to the consumer price index. For example, from 2010 to 2019, it was found that, year by year, using chain-based evolution indices, compared to the previous year, except for 2011 , when this nominal pension increased only to $0.8 \%$, in all other years there were increases, reaching 2017, when it increased by 15\%, in 2018 by $8.9 \%$ and in 2019 by $9.6 \%$. However, taking into account consumer price indices, which he also evolved except in 2015 and 2016 when he was a sub-unit, as a result of administered prices, determined by the VAT reduction from $24 \%$ to $19 \%$, the rest have had increases, so the real rate of change of pensions was much lower, however, being $14.3 \%$ in $2017,5 \%$ in 2018 and $5.6 \%$ in 2019.

An important element that we must consider when conducting this analysis is that of the legislative system, which, as I have said many times, does not fully correspond to the actual situation recorded. For example, it is pursued by the new law of pensions that, for the time being, when writing this article, marked by the Covid crisis 19, which will be followed by an unprecedented economic-financial crisis, the aim was to eliminate an inequity, to adjust to as far as possible the size of pensions by granting higher pensions to those with low incomes, reconsideration of the calculation methodology, recalculations that can be made and many more.

The analysis of the public pension system is important, because this pillar is the basic one, which provides income to all persons who have reached retirement age. The private pensions, respectively pillar 2 and 3, which are functional, complete the pension system in Romania, through Pillar 2, the supplementary pension of all the persons contributing, according to the law, and the Pillar 3 of the individual persons wishing to contribute to the supplementary pension optionally and to obtain an additional pension.

Regarding the evolution of the number of pensioners in Romania, there was a decrease with six thousand retirees in the fourth quarter of 2019 compared to the third quarter of 2019. Thus, the average number of retirees in the fourth quarter of 2019 was 5,140 thousand. The decrease in the number of pensioners was also registered for the whole year, so that in 2019 there was an average number of 5157 thousand pensioners, while in 2018 their average number was 5207 thousand pensioners, thus having an average difference of 50 thousand of pensioners. On the other hand, the average number of state social security pensioners was 4,669 thousand persons in the fourth quarter of 2019, they registered an increase by one thousand compared to the third quarter of 2019.

Regarding the monthly average pension in the fourth quarter of 2019 , calculated taking into account all the categories of pensioners paid by the pension houses, it increased by $9 \%$ compared to the third quarter of 2019, thus reaching the value of 1,412 Ron. At the same time, the average state social insurance pension was RON 1,372, and the ratio between the average nominal state social insurance pension for the full-time retirement age limit and the net average earnings in the fourth quarter of 2019 was 51.1\%, compared to the third quarter of 2019 , when it was $48.7 \%$. 
The average real pension index in the fourth quarter of 2019, calculated as a ratio between the nominal pension index for the calculation of the real pension and the consumer price index, compared to the third quarter of 2019 was $107.8 \%$. The evolution of the nominal pension index and the consumer price index during the period 2017 to 2019 is presented in graph number 1.

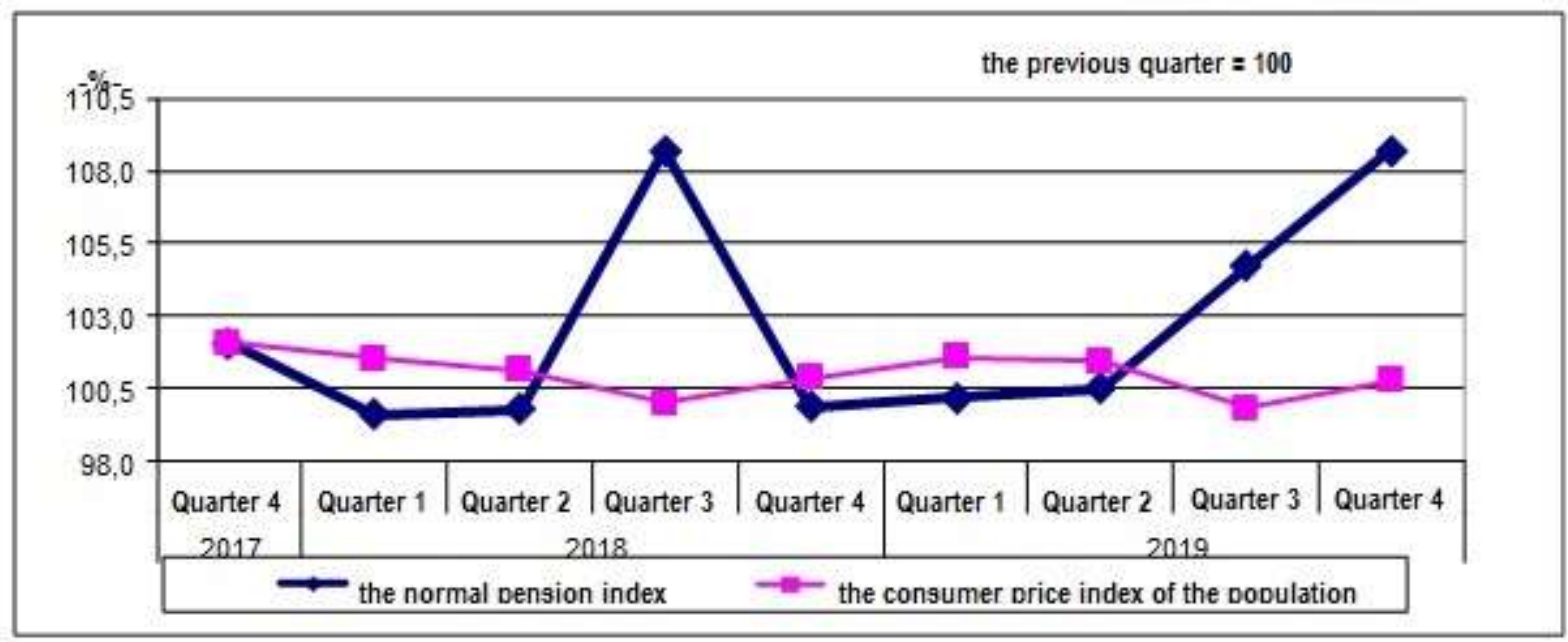

Figure 1. Evolution of the nominal pension index and the consumer price index during the period 20172019

Source: National Institute of Statistics, Press release number 73/16.03.2020

The following is a comparative analysis of the evolution of the average number of pensioners and the average monthly pension in Romania, between the fourth quarter of 2018, the third quarter of 2019 and the fourth quarter of 2019, and the data have been structured in table number 1.

Table 1. The average number of pensioners and the average monthly pension for the period 2018-2019

\begin{tabular}{|l|c|c|c|c|c|c|}
\hline \multirow{2}{*}{} & \multicolumn{3}{|c|}{ Average number } & \multicolumn{3}{c|}{ Average pension } \\
\cline { 2 - 7 } & - thousands of people - & \multicolumn{2}{c|}{ - Ron/monthly - } \\
\cline { 2 - 7 } & $\begin{array}{c}\text { Quarter IV } \\
2018\end{array}$ & $\begin{array}{c}\text { Quarter } \\
\text { III } 2019\end{array}$ & $\begin{array}{c}\text { Quarter IV } \\
2019\end{array}$ & $\begin{array}{c}\text { Quarter IV } \\
2018\end{array}$ & $\begin{array}{c}\text { Quarter } \\
\text { III } 2019\end{array}$ & $\begin{array}{c}\text { Quarter } \\
\text { IV } 2019\end{array}$ \\
\hline TOTAL & $\mathbf{5 1 9 7}$ & $\mathbf{5 1 4 6}$ & $\mathbf{5 1 4 0}$ & $\mathbf{1 2 2 3}$ & $\mathbf{1 2 9 6}$ & $\mathbf{1 4 1 2}$ \\
\hline of which, according to the level of retirement: & $\mathbf{5 1 9 5}$ & $\mathbf{5 1 4 4}$ & $\mathbf{5 1 3 8}$ & $\mathbf{1 2 2 3}$ & $\mathbf{1 2 9 6}$ & $\mathbf{1 4 1 3}$ \\
\hline Social Insurance & 4688 & 4668 & 4669 & 1180 & 1249 & 1372 \\
\hline of which, state social insurance & \multicolumn{3}{|c|}{} \\
\hline of which, social insurance by categories of pensions: & 3999 & 3989 & 3992 & 1376 & 1456 & 1586 \\
\hline A) Age limit & 21 & 19 & 19 & 1423 & 1518 & 1675 \\
\hline B) Early retirement & 90 & 92 & 92 & 1101 & 1186 & 1294 \\
\hline C) Partial early retirement & 536 & 510 & 503 & 659 & 668 & 723 \\
\hline D) Invalidity & 549 & 534 & 532 & 673 & 714 & 771 \\
\hline E) survivor & &
\end{tabular}

Source: National Institute of Statistics, Press release number 73/16.03.2020

Interpreting the data summarized in table number 1 , we find that the social security pensioners hold the highest share in the total number of pensioners, respectively $99.96 \%$. At the same time, the state social security pensioners have a share in the total of social insurance $90.9 \%$. On the other hand, if we follow the evolution by categories of pensions, we find that the number of old-age pensioners had the highest share, namely $\mathbf{7 7 . 7 \%}$ in the social insurance pensioners, and at the opposite pole were the pensioners included in the categories of anticipated and partially anticipated pensions, with a share of only $2.2 \%$.

If we follow the ratio, on the total, between the average number of state social security pensioners and that of the employees, it was from 9 to 10, presenting significant variations in territorial profile. Thus, in Ilfov county the report was of only 4 pensioners for 10 employees, in Teleorman county the report was 
of 16 pensioners for 10 employees, in Giurgiu county the report was of 15 pensioners for 10 employees and in Botoșani, Călărași and Vaslui counties the report there were 14 retirees out of 10 employees.

Regarding the evolution of the average state social insurance pension, this has changed significantly in territorial profile. Thus, the difference between the extreme values was 727 Ron, high pension values being registered in Hunedoara counties with 1,820 Ron, Bucharest Municipality with 1,735 Ron, Brașov county with 1,632 Ron, and lower values of the average pension being recorded in Botosani counties with 1,093 Ron, Giurgiu with 1,100 Ron, Vrancea with 1,120 Ron.

Also, the total number of beneficiaries of the provisions of GEO no. 6/2009 regarding the establishment of the minimum guaranteed social pension, in the fourth quarter of 2019, was 970.1 thousand persons, of which 802.4 thousand persons from the state social insurance system, representing $17.2 \%$ of the total number of pensioners in this category, 164.0 thousand persons among the pensioners from the former system for farmers, representing $57.4 \%$ of their total and 3.7 thousand persons from the military system, representing $2.1 \%$ of the total of this category.

The authors found it useful to analyze the influence of the evolution of the Gross Domestic Product and the average number of pensioners on the evolution of the average monthly pension. Thus, the data collected, regarding these developments between 1990 and 2019, thus having a number of 30 observations for each of the variables analyzed, were structured in table number 2 .

Table 2. Evolution of GDP, average number of pensioners and monthly average pension in Romania between 1990-2019

\begin{tabular}{|c|c|c|c|}
\hline Year & GDP (millions Ron) & $\begin{array}{c}\text { Average number of pensioners } \\
\text { (thousands) }\end{array}$ & $\begin{array}{c}\text { Average monthly pension } \\
\text { (Ron) }\end{array}$ \\
\hline 1990 & 75,5 & 3679 & 13 \\
\hline 1991 & 74,7 & 4131 & 26 \\
\hline 1992 & 201,1 & 4292 & 69 \\
\hline 1993 & 612,1 & 4476 & 21 \\
\hline 1994 & 2082,4 & 4995 & 46 \\
\hline 1995 & 5332,6 & 5258 & 66 \\
\hline 1996 & 7908,0 & 5417 & 96 \\
\hline 1997 & 10835,5 & 5583 & 203 \\
\hline 1998 & 24982,5 & 5755 & 312 \\
\hline 1999 & 36868,3 & 5941 & 532 \\
\hline 2000 & 56483,2 & 6153 & 725 \\
\hline 2001 & 85093,2 & 6351 & 104 \\
\hline 2002 & 124086,2 & 6378 & 134 \\
\hline 2003 & 155836,4 & 6306 & 156 \\
\hline 2004 & 211931,0 & 6233 & 204 \\
\hline 2005 & 256110,7 & 6067 & 246 \\
\hline 2006 & 309893,5 & 5806 & 298 \\
\hline 2007 & 367557,4 & 5745 & 389 \\
\hline 2008 & 465312,2 & 5701 & 572 \\
\hline 2009 & 510049,7 & 5689 & 685 \\
\hline 2010 & 510183,0 & 5675 & 716 \\
\hline 2011 & 538849,8 & 5589 & 753 \\
\hline 2012 & 570861,2 & 5487 & 773 \\
\hline 2013 & 614610,2 & 5410 & 805 \\
\hline 2014 & 657133,8 & 5357 & 846 \\
\hline 2015 & 694474,6 & 5306 & 892 \\
\hline 2016 & 746797,8 & 5257 & 948 \\
\hline 2017 & 819547,6 & 5228 & 1069 \\
\hline 2018 & 895959,3 & 5207 & 1172 \\
\hline 2019 & 991238,2 & 5157 & 1292 \\
\hline & & & \\
\hline
\end{tabular}

Source: National Institute of Statistics. Data processed by the authors 
The evolution of the average number of pensioners and the average monthly pension in Romania during the period 1990 to 2019 is highlighted in the figure number 2.

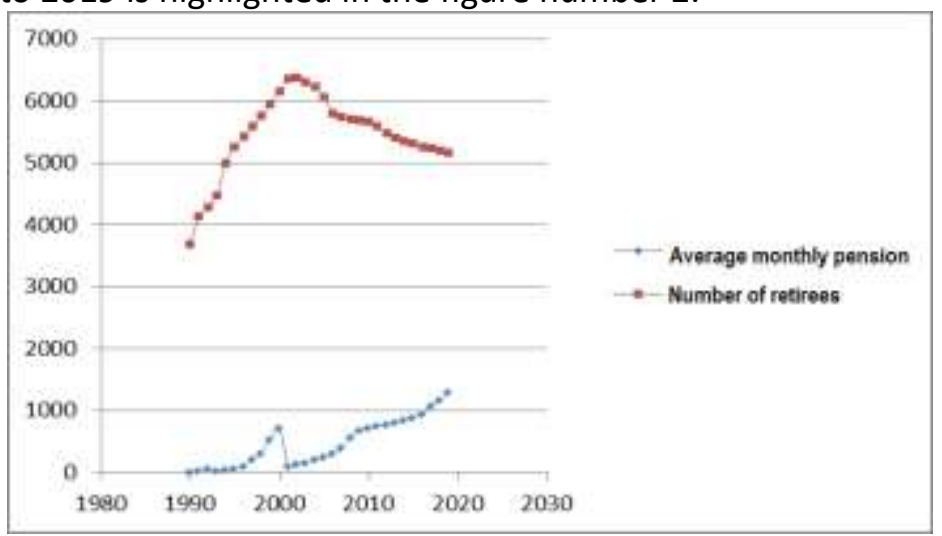

Figure 2. Evolution of the average number of pensioners and the average monthly pension between 1990 and 2019

Analyzing the data from table number 2 and figure number 2, we find that the average number of pensioners in Romania had a positive evolution from 1990 to 2000, when the trend changed, registering constant decreases, year by year, of the number of pensioners, but with a lower intensity than the growth period. At the same time, the value of the monthly average pension registered constant increases with a shock in 2000, reaching a maximum of 1,292 RON in 2019. The histogram of the evolution of the average monthly pension is shown in the chart number 3 .

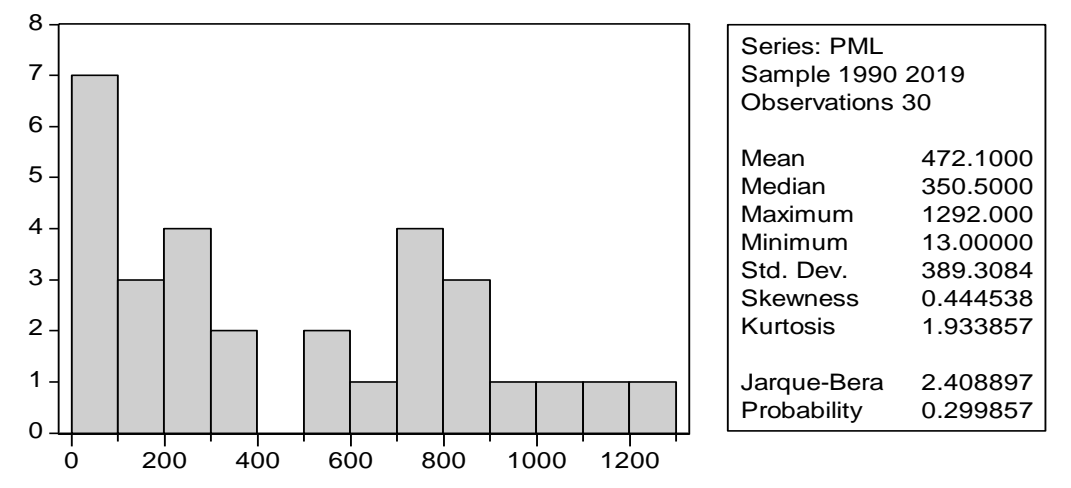

Figure 3. Evolution of the monthly average pension between 1990 and 2019

From figure number 3 it appears that the average value, during the thirty years analysis period, of the monthly average pension is 472.10 Ron, and its maximum is $1,292.00$ Ron, which leads to the conclusion that there has been an accelerated increase in the last years. We also notice that the distribution is slower if we follow the 1.93 value of the Kurtosis test, which is smaller than 3 and at the same time we have a distribution that is not perfectly symmetrical, the Skewness test indicating this by the value of 0.44 which is significantly different from zero. Regarding the histogram of the evolution of the Gross Domestic Product between 1990 and 2019, it is presented in graph number 4 . 


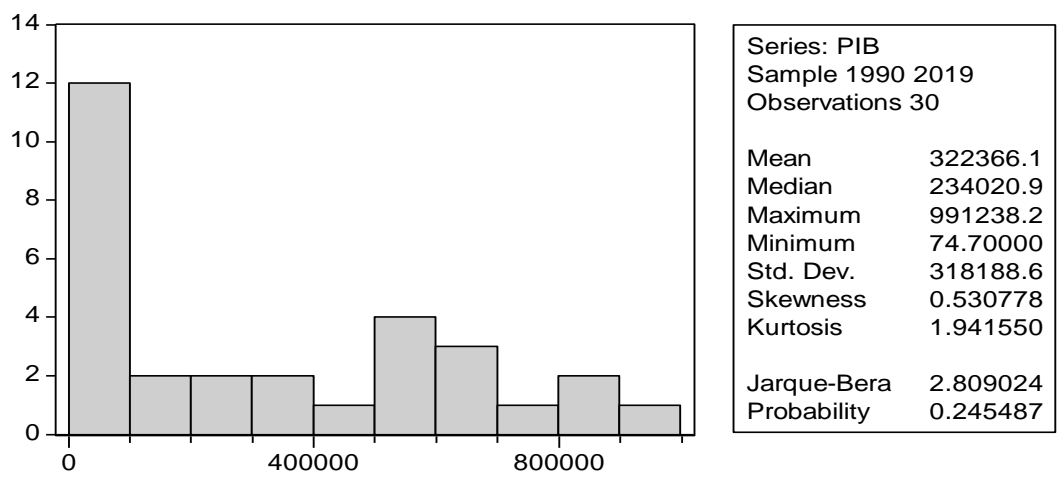

Figure 4. Evolution of Gross Domestic Product between 1990 and 2019

From figure number 4, it appears that the average value of the Gross Domestic Product is RON $322,366.10$ million, and the maximum value is RON 991,238.20 million, three times higher than the average, indicating a faster growth in the last period. We also notice that the distribution is slower if we follow the 1.94 value of the Kurtosis test, which is smaller than 3 and at the same time we have a distribution that is not perfectly symmetrical, the Skewness test indicating this by the value of 0.53 which is significantly different from zero.

The interdependence between the average monthly pension and the Gross Domestic Product is shown in figure number 5 .

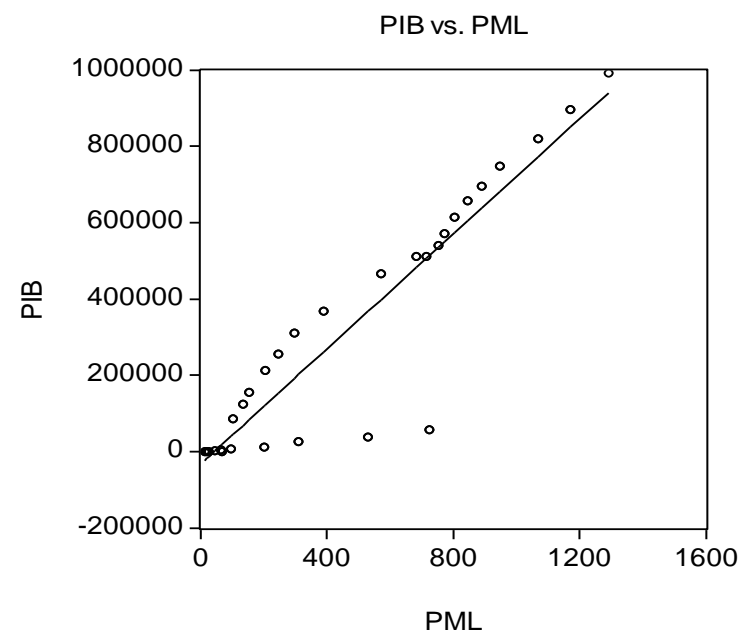

Figure 5. The correlation between the average monthly pension and the Gross Domestic Product

From figure number 5 it can be seen that the point cloud described by the values recorded for the average monthly pension and the Gross Domestic Product describes a line, indicating a linear evolution, which allows the authors to continue with a statistical-econometric analysis using the EViews program. Thus, the simple linear regression equation will have the following form:

$P M L=a+b \cdot P I B+\varepsilon$

Where:

PML represents the average monthly pension (dependent variable); PIB represents the Gross Domestic; $a$ and $b$ represent the parameters of the regression model; $\varepsilon$ represents the residual variable.

The results of the analysis are shown in figure 6 : 
Dependent Variable: PML

Method: Least Squares

Sample: 19902019

Included observations: 30

\begin{tabular}{lllll}
\hline \hline Variable & Coefficient & Std. Error & t-Statistic & Prob. \\
\hline \hline C & 108.6445 & 40.34121 & 2.693140 & 0.0118 \\
PIB & 0.001127 & $8.98 \mathrm{E}-05$ & 12.55457 & 0.0000 \\
\hline \hline R-squared & 0.849152 & Mean dependent var & 472.1000 \\
Adjusted R-squared & 0.843764 & S.D. dependent var & 389.3084 \\
S.E. of regression & 153.8805 & Akaike info criterion & 12.97457 \\
Sum squared resid & 663018.2 & Schwarz criterion & 13.06798 \\
Log likelihood & -192.6186 & F-statistic & 157.6172 \\
Durbin-Watson stat & 0.811664 & Prob(F-statistic) & 0.000000 \\
\hline \hline
\end{tabular}

Figure 6. The results of the simple linear regression between the average monthly pension and the GDP

Interpreting the data obtained and presented in figure number 6 , we find that the model is confirmed by the statistical tests, F-statistic $=157.61$ much higher value than the table and t-Statistic $=2.69$ for the free term, respectively 12.55 for GDP. Also, the value of 0.84 of R-squared is close to the unitary one, thus validating the model. Therefore, the simple linear regression equation that will allow forecasting for the next period has the following expression:

$$
\widehat{P M} \bar{L}=108.6445+0.001127 \cdot \widehat{P I B}
$$

The rather small value of the estimated parameter $\widehat{b}=0.001127$, indicates that the influence of the Gross Domestic Product on the evolution of the value of the monthly average pension in Romania is quite weak and that there are other factors that influence the pensions. As a consequence, the authors set out to introduce in the analysis also the average number of pensioners, statistical data that are presented in the third column of table number 2 . The graph 6 shows the histogram of the evolution of the average number of pensioners in Romania in period 1990-2019.

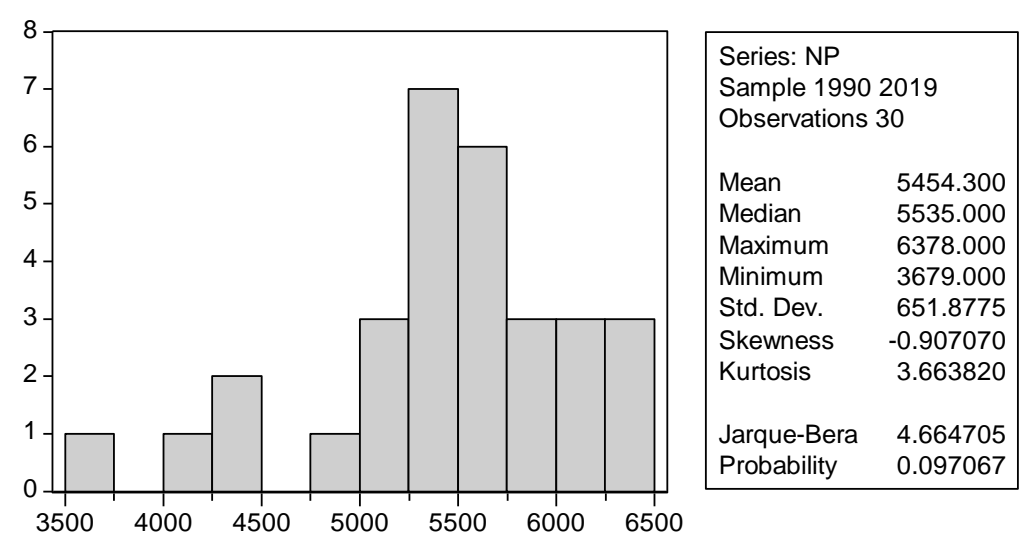

Figure 8. Evolution of the average number of pensioners between 1990 and 2019

From the figure number 8 it appears that the evolution of the average number of pensioners is more blurred or oscillatory, considering that the average value of 5,454.3 thousand pensioners is quite close to the limits (maximum and minimum). The oscillating evolution during this period is also shown in figure number 2. We also notice that the distribution is normal if we follow the value of 3.66 of the Kurtosis test, which is greater than 3 and at the same time we have a distribution that is not perfectly symmetrical, the test Skewness indicating this by the value of -0.90 , which is significantly different from zero.

The statistical-econometric analysis will suppose the approach of the phenomenon using a multiple regression equation, which has the following form: 
$P M L=a+b \cdot P I B+c \cdot N P+\varepsilon$

Where:

PML represents the average monthly pension (the dependent variable);

PIB represents Gross Domestic Product (independent variable);

NP represents the average number of retirees (independent variable);

$a, b$ and $c$ represent the parameters of the regression model;

$\varepsilon$ represents the residual variable.

The results of the analysis are shown in figure 9. Interpreting the data obtained and presented in figure number 9 , we find that the model is confirmed by the F-statistic test, which has a value $(78,17)$ that is much higher than the table. Also, the value of 0.84 of R-squared is close to the unitary one, but regarding the t-Statistics for the average number of pensioners it is not confirmed. The value of 0.81 is lower than the table and the possibility of error is high $42.45 \%$. As a consequence, the model cannot be used for future forecasts.

\begin{tabular}{|c|c|c|c|c|}
\hline Variable & Coefficient & Std. Error & t-Statistic & Prob. \\
\hline $\mathrm{C}$ & -85.44397 & 242.7717 & -0.351952 & 0.7276 \\
\hline PIB & 0.001124 & $9.05 E-05$ & 12.41687 & 0.0000 \\
\hline NP & 0.035815 & 0.044168 & 0.810883 & 0.4245 \\
\hline R-squared & 0.852738 & \multicolumn{2}{|c|}{ Mean dependent var } & 472.1000 \\
\hline Adjusted R-squared & 0.841830 & \multicolumn{2}{|c|}{ S.D. dependent var } & 389.3084 \\
\hline S.E. of regression & 154.8303 & \multicolumn{2}{|c|}{ Akaike info criterion } & 13.01718 \\
\hline Sum squared resid & 647255.6 & \multicolumn{2}{|c|}{ Schwarz criterion } & 13.15730 \\
\hline Log likelihood & -192.2576 & \multicolumn{2}{|c|}{ F-statistic } & 78.17345 \\
\hline Durbin-Watson stat & 0.833001 & \multicolumn{2}{|c|}{ Prob(F-statistic) } & 0.000000 \\
\hline
\end{tabular}

Figure 9. Results of multiple linear regression between monthly average pension, GDP and number of pensioners

\section{Conclusions}

The interpretation of the results presented in this article, based on the study performed on the evolution of the public pension pillar, in the period 1990-2019, compared with the evolution of the number of pensioners and the value of the Gross Domestic Product during the same period of time, draws a series of theoretical conclusions and practical. First, it is found that the public pension system in Romania, from 1990 to the present, has undergone a series of changes determined by the way of calculation, by the way in which certain categories of pensioners are considered, by the way in which they were interpreted. for a time the social aids, which were gradually being generically included in the public pension system.

The evolution of the average annual pension was positive and this was based, first of all, on the growth of the Gross Domestic Product, as an indicator from which the consolidated budget is calculated. We make here an indication that the public pension system in Romania can only evolve and function independently until a future period, when the effect and the two pillars of private pensions will take effect, because so far the employees' pension contributions, they were not highlighted and used for individual purposes to obtain net higher values.

The second conclusion to be drawn from the analysis of public pension funds is that this is still far from meeting the growing needs of the population (pensioners), especially when the harmonized index of consumer prices (as well as the consumer price index), raise and really affect the level of pensions received.

The use of the two statistical-econometric methods, for the calculation of the parameters based on which the estimation and forecast of the evolution of the public pension can be made, is not limiting because, this kind of analysis can be extended by using other statistical-econometric variables. In a future 
period, maybe in June or September this year, an analysis can be made of the impact of the coronavirus pandemic crisis, which caused the economic crisis, on the evolution of the annual average real pension. We say this because, in the next period, an increase in the inflation index is expected, both in the form of the aggregate price index and the consumer price index. This will be emphasized both by reducing the supply of goods of all categories (food, non-food, services on the market) and as a result of the negative effects that the economic crisis has on the economic agents who, based on a reduced supply, prices will rise.

A final conclusion is that at the moment the evolution of the growth rate of the public pension is marked by some uncertainty, due to the impossibility of approving the measures to increase the pension point, according to the last law of the pensions in our country, of the recalculation of pensions or depends on what other elements may reveal the forthcoming economic-financial crisis. 


\section{References}

1. Andonov, A., Hochberg, Y., Rauh, J. (2018). Political Representation and Governance: Evidence from the Investment Decisions of Public Pension Funds. The Journal of Finance, 73 (5), 1967-2466.

2. Anghel, M. G., Anghelache, C. (2018). Analysis of the evolution of the number of pensioners and pensions in Romania. Theoretical and Applied Economics, XXV (2) (615), Summer, 187-194.

3. Anghelache, C. (2018). Bilanțul economic al României la 100 de ani, Editura Economică, Bucureşti

4. Anghelache, C., Voineagu, V., Anton-Carp, A. (2011). Elemente teoretice şi practice privind algoritmul de calcul al pensiilor. Romanian Statistical Review Supplement, Trim. 3, 107-119.

5. Biggs, A. (2014). The public pension quadrilemma: the intersection of investment risk and contribution risk. Journal of Retirement, 2 (1), 115-127.

6. Bohn, H. (2011). Should Public Retirement Plans Be Fully Funded?. Journal of Pension Economics and Finance, 10, (02), 195-219.

7. Bouchet, M., Marchiori, L., Pierrard, O. (2017). Pension reform in a worst case scenario: public finance versus political feasibility. Journal of Pension Economics and Finance, 16, (2), 173-204.

8. Cai, J., Stoyanov, A. (2016). Population aging and comparative advantage. Journal of International Economics, 102, 1-21

9. Chen, D., Beetsma, R., Ponds, E., Romp, W. (2016). Intergenerational risk-sharing through funded pensions and public debt. Journal of Pension Economics and Finance, 15 (2), 127-159.

10.Hairault, J., Langot, F., Sopraseuth, T. (2010). Distance to Retirement and Older Workers' Employment: The Case for Delaying the Retirement Age. Journal of the European Economic Association, 8 (5), 1034-1076.

11.lacob, Ș. V. (2019). Utilizarea metodelor statistico-econometrice și econofizice în analize economice, Editura Economică, Bucureşti.

12.Novy-Marx, R., Rauh, J. (2011). Public Pension Promises: How Big Are They and What Are They Worth?. Journal of Finance, 66 (4), 1211-1249.

13.Roeder, K. (2014). Optimal Taxes and Pensions with Myopic Agents. Social Choice and Welfare, 42 (3), 597-618.

14.St. Clair, T., Martinez Guzman, J.P. (2018). Contribution volatility and public pension reform. Journal of Pension Economics \& Finance, 17 (4), 513-533.

15.Vogel, E., Ludwig, A., Börsch-Supan, A. (2017). Aging and pension reform: extending the retirement age and human capital formation. Journal of Pension Economics and Finance, 16 (1), 81-107.

16.Institutul Național de Statistică, Comunicat numărul 73/16.03.2020. 